\title{
大腿骨骨萎縮の予防に関する実験的研究
}

\author{
殷 祥 洙*1 益子詔次*2 山内 秀樹*1 \\ 猪飼 哲夫*3 米本 恭三*4
}

\section{The Experimental Study for Preventing Disuse Osteoporosis}

\author{
Eun Sang Soo, ${ }^{* 1}$ Shoji Mashiko, ${ }^{* 2}$ Hideki Yamauchi, ${ }^{* 1}$ \\ Tetsuo IKaI, ${ }^{* 3}$ Kyozo Yonemoto**
}

\begin{abstract}
The purpose of this study is to investigate the efficacy of exercise to prevent disuse osteoporosis in femurs of rats. The jump exercise was selected in this study because it had been reported as one of the most effective resistance training to gain bone mass. Twenty-four of 6 month-old, F 344, female rats were divided into three groups equally; control group (CONT), hindlimb suspension group (HS), and hindlimb suspension with jump exercise group (HS+EX). A Kirschner wire that was attached to the ceiling of the cage penetrated each tail of HS and HS+EX rat, and then her hindlimbs were unloaded from gravity. HS + EX rats were taken off from tail suspension and forced to jump during the exercise. When HS+EX rats jump up, they grasped the top of the $30 \mathrm{~cm}$ height with their forelimbs and climbed up to the top. After each jump, they were replaced gently to the bottom by hands in preparation for the next jump so as to exclude the impact made by dropping down. HS +EX rats were suspended again when they finished 50 jumps a day, which were held on 5 days a week. All groups of the rats were fed for 8 weeks, and then their femurs were harvested. Bone mineral densities, mechanical bone properties, and morphological analysis of all femurs were measured. The femurs of HS rats showed a significant decrease in bone mineral density and maximum bending load compared with the control ones, but the femurs of HS + EX rats showed almost the same degree of these parameters as those of the CONT rats. The same tendencies were observed in the bone length and diameter. So we concluded that the dynamic resistance training like our jump exercise was thought to be effective for preventing disuse osteoporosis. (Jpn J Rehabil Med 2001; $38: 203-210$ )
\end{abstract}

要 旨：寝たきり老人における廃用性骨粗鬆症に対する，予防的なりハビリテーションが近 年重要視されている. 今回我々は廃用状態下のラットにおける運動負荷が，その大腿骨に及ほ す影響について検討した。廃用ラットは後肢懸垂法により作成し，期間は 8 週間とした。運動 は骨量増加に対する有用性が認められている動的抵抗運動である，ジャンプ運動を用いた。実 験の結果, 後肢懸垂群では骨密度扔よび最大曲げ荷重量が有意に低下したのに対し，後肢懸垂 中にジャンプ運動を行った群では通常飼育群と差を認めなかった。したがって動的抵抗運動が 廃用症候群を来す環境下での骨萎縮の予防法として有用と考えられた。（リハ医学 $2001 ； 38$ ： 203-210)

2000 年 3 月 8 日受付, 2001 年 2 月 7 日受理

*1 東京慈恵会医科大学リハビリテーション医学講座/テ 201-8601 東京都狛江市和泉本町 4-11-1

Department of Rehabilitation Medicine, Jikei University, School of Medicine

*2 宇都宮大学教育学部/ ₹ 321-8505 栃木県宇都宮市峰町 350

Faculty of Education, Utsunomiya University

*3 東京都リハビリテーション病院/テ 131-0034 東京都墨田区堤通 2-14-1

Tokyo Metropolitan Rehabilitation Hospital

*4 東京都立保健科学大学/ $7116-8551$ 東京都荒川区東尾久 7-2-10

Tokyo Metropolitan University of Health Sciences 
Key words : ジャンプ運動（jump exercise）, 後肢懸垂 (hindlimb suspension), 骨密度 (bone mineral density), 動的抵抗運動 (dynamic resistance training), リ ハビリテーション (rehabilitation)

\section{緒言}

近年骨粗鬆症に対するさまざまな予防法が提唱され ている.とりわけ習慣的な運動負荷の効果を検討した 報告によれば，健康な閉経前後の女性では，ジャンプ 運動により有意な大腿骨頸部の骨密度の増加が認めら れている1)。また動物実験においても，卵巣摘出によ る閉経モデルラットに対しトレッドミルによる走運動 が骨量低下の予防に有用であることが報告されてい る2).これらの結果は主に内分泌系異常に起因する閉 経後骨粗鬆症に対する予防法として，運動が有用であ ることを示唆する。一方，長期臥床などによる廃用状 態がもたらす骨粗鬆症では，廃用による骨の病態変化 の検討，薬剤の効果に関する報告は見られるが，骨粗 鬆症に対する運動の効果を検討した報告は少ない。人 体において廃用性骨粗鬆症の問題は骨格筋の筋活動と 密接な関係を認め，転倒による骨折の危険とも関連付 けられており ${ }^{3)}$ ，廃用状態下における運動の実践は， 骨量維持効果にとどまらず転倒防止の訓練にもなりう ると思われる．これらの意味から，廃用状態下の運動 効果を検討することはリハビリテーション分野におい て重要であると思われる，廃用症候群をもたらす状況 として，頸髄損傷による四肢麻痺では通常 $2 \sim 3$ 力月 で 1 サイクルを終える骨代謝回転が半年間以上に延 び4)，脳卒中片麻痺患者では麻痺肢の骨密度が健肢に 比し有意に低下していたという報告5)がある。このよ うな臨床疾患に対する基礎研究モデルから骨の特性変 化が検討されているが，運動負荷の効果を調べる実験 系としては適していない. 後肢㲘垂法は動物の後肢を 非荷重状態にするモデルで，廃用性の病態変化を調べ ることに頻用されている．脊髄損傷のように筋が完全 に不動化（廃用）になるわけではないが，早期に筋萎 縮が確認されているため，廃用による骨の変化や運動 効果を実証可能であり，本研究に合った実験系と考え られる。廃用性骨萎縮に対する運動効果に関しては, ラットの後肢懸垂解除後のジャンプ運動が有効であっ たという報告が見られるが6), 後肢懸垂期間中の運動 効果についての報告は見られない，しかしこの状態の 実験モデルを作り出すことが，より臨床に即したもの
と思われる.したがって，今回我々は廃用モデルとし て後肢懸垂ラットを用い, ジャンプ運動による大腿骨 骨萎縮の予防効果について検討した。

\section{対象および実験方法}

\section{1. 実 験 動物}

SLC, Inc.（浜松）より購入した F 344 系，雌， 6 カ月齢のラット 24 匹（平均体重約 $240 \mathrm{~g}$ ) を, 対照 群 (control: CONT), 後肢懸垂群 (hindlimb suspension: HS), 後肢懸垂十運動群 (hindlimb suspension+exercise : HS+EX) に3 群化した。各群 のラットは無作為に 8 匹ずつとした.CONT 群は後 肢懸垂および特別な運動負荷を行わない通常飼育群 とした，尾骨に貫通させた径 $1.0 \mathrm{~mm}$ の Kirschner wire を飼育ケージの天井にサル環を介して固定する ことにより，HS 群および HS+EX 群のラットの後 肢を非荷重とした。この際ラットは前肢により移動可 能であり，摂慨・摂水に支障がないことを確認した。 すべてのラットは個別の飼育ケージによって飼育さ れ，摂慨・摂水を自由とし，飼育期間は 8 週とした。 実験遂行に関しては「生理学領域における実験動物に 関する基本的指針」（日本生理学会制定）を遵守した。

\section{2. 運動負荷方法}

本実験に先立つ 1 週間の予備飼育期間に, HS + EX 群のラットに対し, 床からの電気刺激によりジャンプ 動作に対する条件付けを行った。これによりラットは 電気刺激なしで $30 \mathrm{~cm}$ のジャンプが可能となった。 $\mathrm{HS}+\mathrm{EX}$ 群のラットは高さ $30 \mathrm{~cm}$ のジャンプ運動を 1 日 50 回，週 5 日， 8 週間の懸垂実験期間中行った。 ラットが床面からジャンプし，前肢により高さ $30 \mathrm{~cm}$ の上縁によじ登るまでを 1 回の運動とし, 着地の衝撃 を避けるため静かに底面に戻した，既にジャンプを条 件付けられたラットに対し, 実験期間中に電気刺激に よりジャンプ動作を促す機会はほとんどなかった。 50 回のジャンプ施行には約 5 分を要し，その終了後は後 肢懸垂状態に戻した。

\section{3. 測 定 項目}

エーテルによる深麻酔で呼吸停止後, 直ちに飼育し たラットの両側後肢より大腿骨を摘出した。次に右側 
大腿骨の二重エネルギー X 線吸収測定法（DXA 法） による骨密度（BMD）の測定，および左側大腿骨で 静的 3 点曲げ試験と断面破断特性の測定を行った.

1）BMD：軟部組織を取り除いたラットの大腿骨 を, 水深 $1.5 \mathrm{~cm}$ の蒸留水を浸したアクリル製容器の 底面に, 内側顆, 外側顆, 転子部, 骨頭部の 4 点支持 で保持し，Hologic 社製 QDR 2000 の ultra-high resolution modeで骨全体をスキャンした。ディスプレ イ上で 4 つの関心領域，すなわち骨頭頸部（骨頭すべ てを含み大転子と小転子を結ぶ線まで），転子部（骨 頭頸部領域に連続して大転子，小転子すべてを含む)， 骨幹部（転子部領域に連続して内側上顆，外側上顆を 結ぶ線まで)，顆部（骨幹部領域に連続して外側顆, 内側顆すべてを含む）に分け BMD を算出した。

2）静的 3 点曲げ試験：骨長，骨幹部の短径・長径 をキャリパーにて測定した後, 骨破断測定装置（アイ テクノ社製 Rheolometer Max RX 1600）を用い，骨 長の中央部において, 静的 3 点曲げ試験を行った。こ の際大腿骨の支持幅は $20 \mathrm{~mm}$, プランジャーの破断

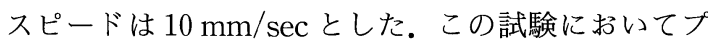
ランジャーが大腿骨を破断する時に加わる力の最大值 を最大曲げ荷重量とした。

3）断面 2 次モーメントの計測：静的 3 点曲げ試験 によって破断された大腿骨の破断面を, 正確に接着復 元し樹脂包埋した。この状態で長軸に対して垂直に破 断部位を切断し，切断面を写真撮影した。グラフィッ クデジタイザー（KB 9060 N II およびNEC 9801 BX 3）および 2 次元図形解析プログラム7)を用い, 得られた写真の断面測定值を求め, 断面 2 次モーメン トを算出した。

\section{4. 統計処理}

各群の值は平均値と標準偏差で表した。平均值の差 の検定は, 分散分析法による測定を行い, 有意差が見 られたものについて Fisherの多重比較検定を行った。 両者とも5\%の危険率をもって有意とした。

\section{結果}

\section{1. 実験期間中の体重変化}

各群の実験期間中の体重変化を図 1 に示す．実験終 了時には HS 群が CONT 群に比し有意に低值であっ た．経時的変化としては, CONT 群, HS+EX 群に 関して，実験開始時と終了時との間に有意な体重変化 が見られなかったが, HS 群に関しては有意に体重が

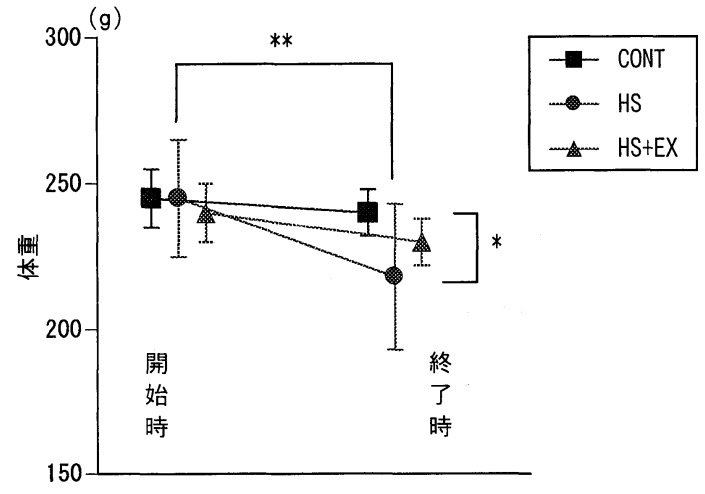

図 1 ラットの体重変化

実験開始時の 3 群間に有意な体重の差は見られなかった が，実験終了時に HS 群はCONT 群に比し有意に体重が 減少した。HS群に関しては実験経過中に有意に体重が減 少した $\left(* p<0.05,{ }^{* *} p<0.005\right)$.

減少した.

\section{BMD の変化}

各群の BMD を図 2 に示した。骨頭頸部で CONT 群に比し $\mathrm{HS}$ 群は平均 $8.5 \%$, HS + EX 群は平均 5\% BMD が有意に低下したが, HS 群と HS+EX 群との 間に有意差は見られなかった。転子部，骨幹部，顆部 でもHS 群はCONT 群に比しそれぞれ $10 \% ， 6 \%$, $8 \% \mathrm{BMD}$ が有意に低下したが, HS+EX 群は HS 群 に比しそれぞれ 7\%，5\%，5\%有意に増加した。しか も転子部，骨幹部，顆部においてはCONT群と $\mathrm{HS}+\mathrm{EX}$ 群との間に BMD の有意差は見られなかっ た.

\section{3. 断面破断特性の変化}

各群の最大曲げ荷重量, 断面 2 次モーメント, 曲げ ストレスを図 3 に示した. HS 群は CONT 群に比し, 平均 $13 \%$ 最大曲げ荷重量が有意に低下したが，HS+ EX 群はHS 群に比し平均 $12 \%$ 高值を示した。 $\mathrm{CONT}$ 群と HS+EX 群とに有意差は見られなかっ た. 断面 2 次モーメント, 曲げストレスについては 3 群間において有意差が認められなかった。

\section{4. 大腿骨長および大腿骨径}

各群の大腿骨長および長径，短径の平均值を図 4 に 示す.HS 群はCONT 群に比し大腿骨長と長径がそ れぞれ $2 \% ， 4 \%$ 有意に低下したが，HS+EX 群は HS 群に比しそれぞれ $2 \%, 5 \%$ 有意に増加した。 CONT 群と HS+EX 群との間に有意差は見られなか った。また短径に関しては 3 群間に有意差は見られな 

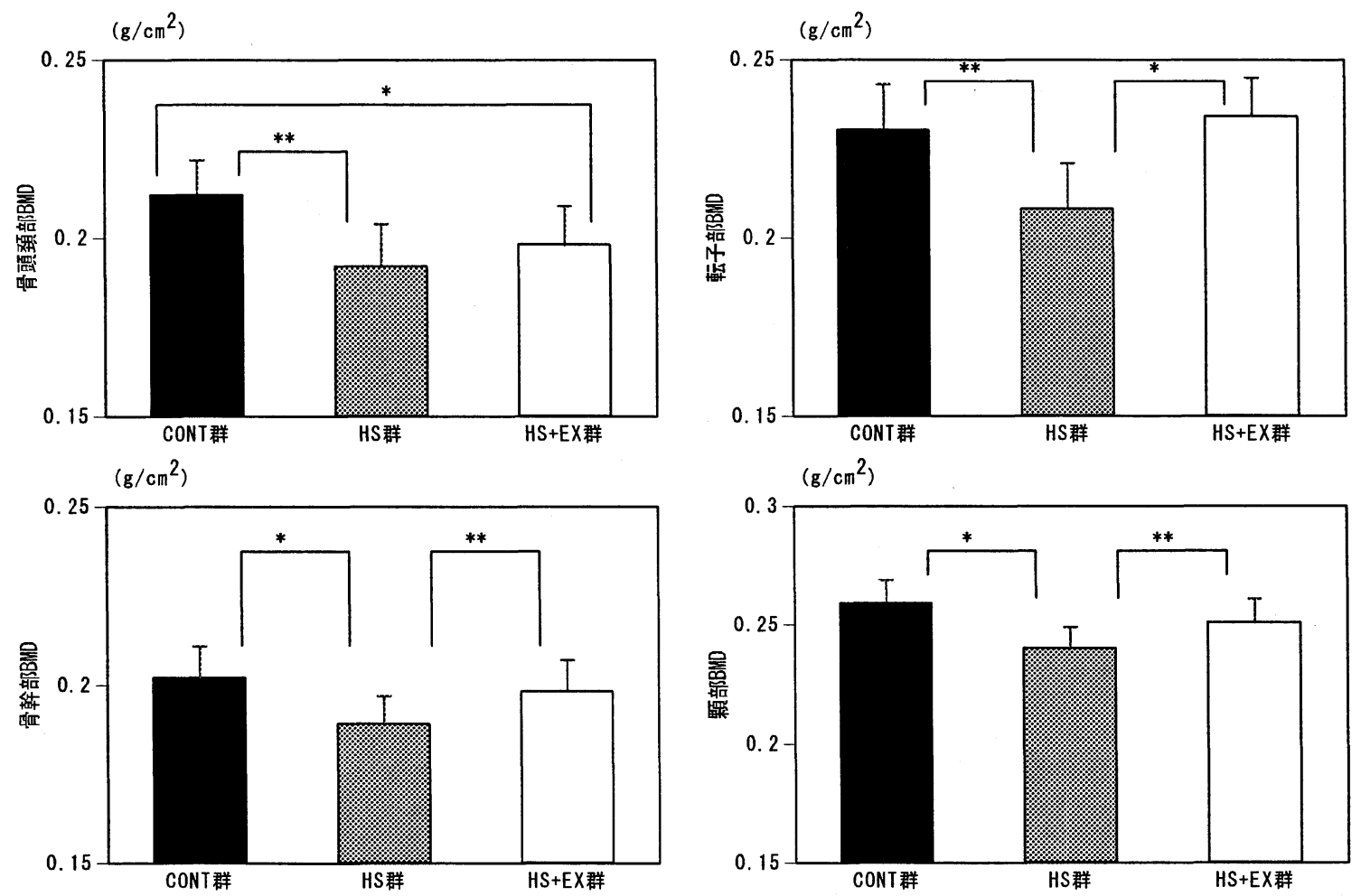

図 2 各群における部位別骨密度

骨頭頸部では，HS 群が CONT 群に比し有意に BMD の低下が見られが，HS+EX 群とに有意差は見られなかった．転 子部，骨幹部，顆部でも，HS 群は CONT 群に比し有意に低下したが，HS+EX 群は HS 群に比し有意に増加した。し かも転子部，骨幹部，顆部においては CONT 群と HS + EX 群に有意差は見られなかった $\left({ }^{*} p<0.05,{ }^{* *} p<0.005\right)$.

かった.

\section{考察}

\section{1. 実験系について}

今回の研究の主目的は，廃用性骨粗鬆症を予防する ための運動効果を証明することであった。しかし廃用 状態を同一の条件に設定することが人体では極めて困 難であるため，性，年齢が同一の F 344 系ラットを用 いた実験を行った，実験動物，特にラットに廃用状態 をもたらす方法として，坐骨神経切断による不動化8) や，微小重力空間における飼育 ${ }^{9)}$ ，ギプス固定，後肢 懸垂による後肢の非荷重等があり，筋量の低下や骨萎 縮の進行が報告されている。これらの中でも，後肢懸 垂による方法は一定時間の懸垂の解除により毎日の運 動が可能という利点があり，かつ過去の報告例もない ため，これを廃用状態下での運動のモデルとした。

実験の骨に対する影響を測定する方法の中で，一般 に用いられているのは BMD の測定である，その測定
法として現在臨床で一般的に用いられているのは DXA 法であり，その有用性はよく知られている。し たがって，今回我々は DXA 法を用い，ラット大腿骨 BMD を測定した。

また，実際に骨を破断することにより骨の特性を調 べる方法がある．この際，骨の加圧に耐えうる物理的 な力は骨の断面形態によって異なってくると考えら れ，実験によるその変化についての報告もされてい る ${ }^{10)}$.したがって今回の実験では 3 点曲げ試験による 最大曲げ荷重量の測定とともに，その破断部における 断面特性値を計測した。

\section{2. 後肢懸垂の影響について}

後肢懸垂に関する先行研究においては，4 日間の後 肢懸垂による骨梁，骨端組織，類骨組織の有意な減 少 ${ }^{11)}, 1$ 週間の後肢懸垂による大腿骨皮質断面積の有 意な減少 ${ }^{12)}$ という報告がある，骨に対する力学的負 荷が骨組織に圧電位を生じさせ，骨にカルシウムイオ ンを沈着させること，また骨芽細胞が直接活性化する 


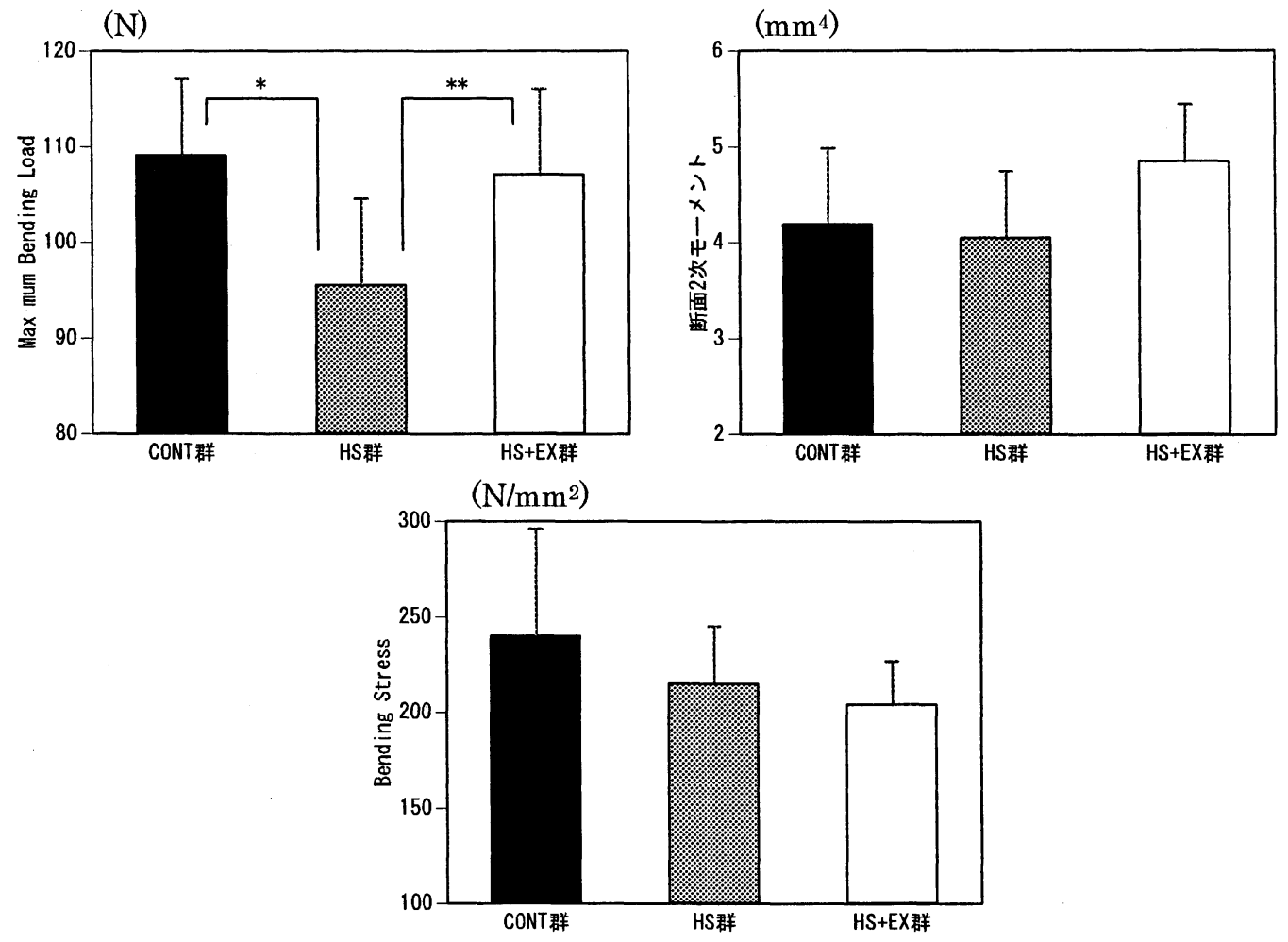

図 3 各群における最大曲げ荷重量, 断面 2 次モーメント, Bending Stress の比較

HS 群は CONT 群に比し, 最大曲げ荷重量が有意に低下したが, HS+EX 群は HS 群に比し, 平均 12\%増加し た. CONT 群と HS+EX 群とに有意差は見られなかった. 断面 2 次モーメント, Bending Stress に関しては, 各群間に有意差は見られなかった $\left({ }^{*} p<0.05,{ }^{* *} p<0.005\right)$.
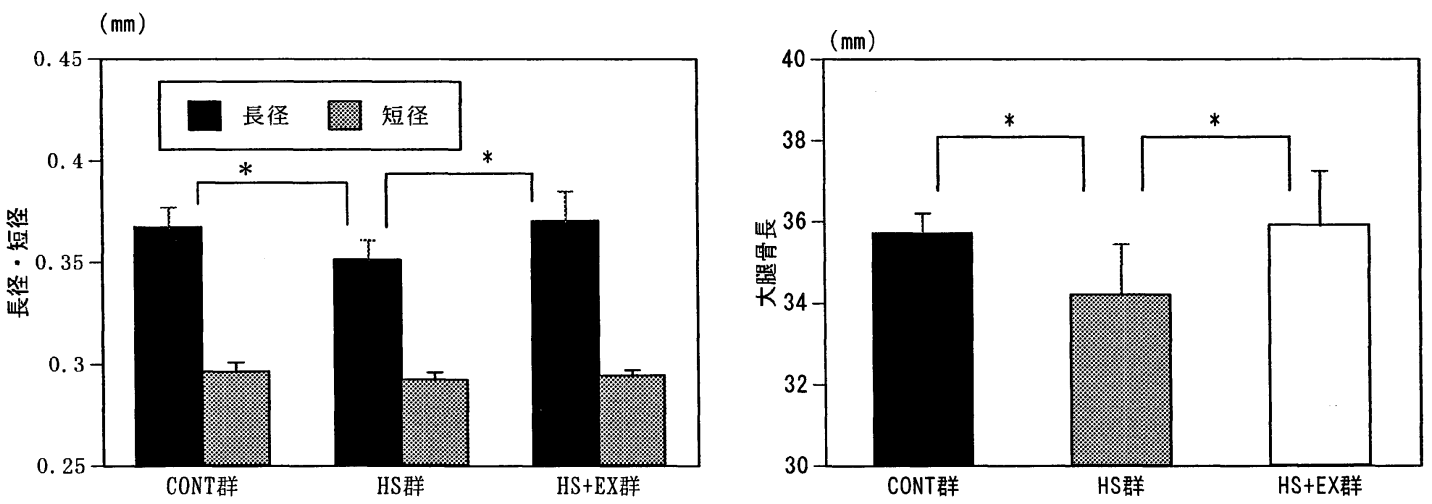

図 4 各群に扔ける長径・短径・骨長

HS 群は CONT 群に比し，大腿骨長が有意に低下したが，HS+EX 群は HS 群に比し，大腿骨長および長径が有意に 増加した。CONT 群と HS+EX 群とに有意差は見られなかった。また短径に関しては，3群間に有意差は見られなか った $\left({ }^{*} p<0.05\right)$. 
こと, 骨内血流の増加を介して骨芽細胞が活性化する ことが想定されている ${ }^{13)}$ ．また非荷重では破骨細胞の 活性化を来すと言われている ${ }^{13)}$.この際に down reg-

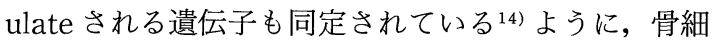
胞はその刺激を感知し，骨の細胞機能を調節している と考えられる. 今回の実験では 8 週間の後肢懸垂によ り, 大腿骨 BMD と最大曲げ荷重量の低下といった廃 用性骨萎縮が観察された。つまりこの期間中大腿骨に 対して力学的負荷を及ぼさなかった結果, 圧電位の消 失，骨芽細胞の不活化と破骨細胞の活性化を来してい たことが想定される。

後肢懸垂の際に骨代謝マーカーを用い, 骨代謝の経 時的変化をとらえた報告もある. 黒河内らは後肢懸垂 ラットを 2 週間にわたり飼育した結果，骨吸収マーカ 一である尿中ピリジノリン排泄や TRAPmRNA が懸 垂 1 日目より 3 日目まで上昇し, 非荷重早期に骨吸収 の促進, および破骨細胞の活性化が図られ, 懸垂 5 日目以降から骨吸収マーカーである ALPmRNA, BGPmRNA, I 型コラーゲン mRNA が低下し, 非 荷重の持続により骨形成が抑制されることを報告し た ${ }^{15)}$.つまり本実験においても懸垂開始早期よりすで に骨吸収は促進し，かつ８週間にわたり骨形成が抑制 されていたことが示唆される。

\section{3. 後肢懸垂中の運動について}

運動の方法については, 低強度の負荷を繰り返し行 うより, 強度の負荷を行うほうが有効であるという報 告があり ${ }^{1)}$, 近年ジャンプ運動の有用性が報告されて いる ${ }^{16)}$. 梅村らは 4 週齡の F 344 系雌ラットをコント ロール群, 自発走運動群, ジャンプ運動群の 3 群に分 け，8週間飼育した. ジャンプ運動群に対しては 1 日 100 回，週 5 日間のジャンプを $25 \mathrm{~cm}$ から開始し, 1 週ごとに $5 \mathrm{~cm}$ ずつ漸増し, 第 4 週から $40 \mathrm{~cm}$ とし た。これによって得られたジャンプ運動群のラット大 腿骨の骨強度は, 自発走運動群, コントロール群に対 し有意に増加したと報告した ${ }^{17)}$. 加えて彼らは 5 週齡 のラットを 1 日 5 回, 10 回, 20 回, 40 回, 100 回ジ ヤンプさせる群に分け，これを週 5 日間，8週間にわ たり施行しコントロール群と比較したところ，5回以 上ジャンプを行う群はコントロール群に比し大腿骨, 脛骨の骨強度がすべて有意に堌加したと報告した ${ }^{16)}$. トレッドミルを用いた走運動により BMD の増加が見 られたという報告も散見される18,19) が，ジャンプ運 動はトレッドミルに比し短時間で行える長所があるた
め, 本研究においても懸垂解除時間の短縮が可能と考 えられた. しかも本研究のごとく底面への着地を愛護 的に行えば, 走運動とは異なり, 着地による衝撃の要 素を除外することができる，すなわちジャンプ運動の 主体は, 飛び上がり時の重力に対する後肢筋群の抵抗 運動と考えられるため, 走運動等よりも廃用状態下で の運動の検討として適当であると思われる。したがっ て今回我々は, 後肢懸垂ラットに対する運動としてジ ヤンプ運動を選択した。

また運動の負荷量の設定についての検討も必要であ る. $60 \% \mathrm{VO}_{2} \max$ の運動を 3 週間以上継続すると骨 形成を促進するという研究20)がある一方, $80 \% \mathrm{VO}_{2}$ max の運動を 11 週間継続したらラット脛骨の BMD が低下したとの報告 ${ }^{21}$ もあり, 過剩な負荷が骨萎縮 の原因になり得ると考えられる. 前述の梅村らの研究 においては，1日のジャンプ数が $5 \sim 100$ 回の各群間 で同様の効果を得たと報告した ${ }^{16)}$. 今回の実験は後肢 懸垂ラットの運動であるため, 5 分程度の懸垂解除で 充分な運動効果が予想される, 週 5 回, 1 日 50 回, $30 \mathrm{~cm}$ の高さでのジャンプ運動を施行することとし た.

本実験の結果, HS 群ラットの体重減少, BMD と 最大曲げ荷重量の低下を認めたが, HS+EX 群のラ ットは, CONT群のラットとほほ同等の体重, BMD, 最大曲げ荷重量であった。つまり後肢懸垂に よる廃用性骨萎縮はジャンプトーニングにより予防し 得ると考えられた.HS 群ラットの体重減少は抗重力 筋の萎縮が主な原因と考えられる22) が, HS+EX 群 ラットは 1 日 5 分程度のジャンプ運動によっても廃用 状態下での抗重力筋の萎縮が予防できたことに加え, その筋収縮活動の骨に対する力学的負荷が, 前述した 圧電位の発生と骨芽細胞の活性化をもたらすことによ り, 体重減少と骨萎縮を来さなかったと考えられる.

なお骨形態に関しては，ジャンプ運動により 5 週齡 の成長期ラットの断面 2 次モーメントが増加したとい う報告がある ${ }^{16)}$. しかし CONT 群のラットは 8 週間 後も有意な体重変化は認められず，この間のラットの 成長による影響が除外できると考えられた。したがっ て成長期ラットとは異なり, ジャンプ運動により骨の 物性としての強度の増加に起因すると思われる最大曲 げ荷重量の増加がみられても, 骨の構造力学的な強度 に対して影響を及潘すには至らなかったと考元られ る. 
本実験における後肢懸垂中のジャンプ運動の意義 は，長期臥床や宇宙空間といった骨への荷重が不可能 な状態での運動の有用性を示唆している.ジャンプ運 動は一見重力の影響がないと不可能な, high impact な運動のようだが，実際には前述したようにラット後 肢筋群の重力に対する動的抵抗運動が主であると考え られる. 近年抵抗運動の骨に対する有用性が唱えられ ており ${ }^{23)}$, 今回の実験でも, high impactなエネルギ 一が存在しなくとも，ある抵抗に対する下肢筋群の求 心性・遠心性収縮が，骨萎縮の予防に有効であるとい うことを示唆している。よって臥位を保たなければな らない状況等でも, 動的抵抗運動は骨強度の維持ある いは増加を促す可能性が考えられる。

\section{結語}

下肢を非荷重の状態にして廃用性骨萎縮を招く環境 下でも，本実験のような短時間の運動により， BMD および最大曲げ荷重量が正常に保たれたという結果を 得た。

本研究全般にわたりご指導頂いた東京慈恵会医科大学り ハビリテーション医学講座教授宮野佐年先生, BMD 測定 にご便宜を頂いた国立療養所東宇都宮病院リハビリテーシ ヨン科河井宏之先生，骨断面形態測定にご便宜を頂いた防 衛医科大学校生物学科松村秋芳先生，実験の施行にあたり 数々のご協力を頂いた宇都宮大学教育学研究科大類竜矢君 に深謝いたします。

本研究の要旨は第 36 回日本リハビリテーション医学会 学術集会，および第 3 回 International Congress of Pathophysiology（Finland）に発表した.

\section{文献}

1) Heinonen $A$, Kannus $P$, Sievanen $H$, Oja P, Pasanen M, Rinne M, Uusi-Rasi K, Vuori I : Randomised controlled trial of high-impact exercise on selected risk factors for osteoporotic fractures. Lancet 1996 ; 348 : 1343-1347

2) Peng Z, Tuukkanen J, Vaananen HK : Exercise can provide protection against bone loss and prevent the decrease in mechanical strength of femoral neck in ovariectomized rats. J Bone Miner Res 1994; 9 : 1559-1564

3) Jerilynn C, Susan I, Raphael C, Robert A : Physical activity as therapy for osteoporosis. Can Med Assoc J 1996 ; 155 : 940-944

4) Minaire $P$, Neunier $P$, Edouard J, Courpron $P$, Bourret J : Quantitative histological data on disuse osteoporosis: comparison with biological data. Calcif Tissue Res $1974 ; 17: 57-73$
5）猪飼哲夫, 米本恭三, 宮野佐年, 小林一成, 福田千晶, 杉 本 淳, 安保雅博: $\mathrm{MD} / \mathrm{MS}$ 法による脳卒中片麻舫患 者の骨萎縮の検討. 総合リハ 1991；19：1001-1004

6) Bourrin S, Palle S, Genty C, Alexandre C: Physical exercise during remobilization restores a normal bone trabecular network after tail suspensioninduced osteopenia in young rats. J Bone Miner Res $1995 ; \mathbf{1 0}: 820-828$

7）高橋秀雄, 足立和隆：ディジタイザによる 2 次元図形 解析プログラム．インターフェース 1982； (4) : 200214

8) Brighton CT, Tadduni GT, Pollack SR : Treatment of sciatic denervation disuse osteoporosis in the rat tibia with capacitively coupled electrical stimulation. Dose response and duty cycle. J Bone Joint Surg [Am] $1985 ; 67$ : 1022-1028

9) Carmeliet G, Bouillon R: The effect of microgravity on morphology and gene expression of osteoblasts in vitro. FASEB J 1999; 13 Suppl: S $129-134$

10) Peng $Z$, Tuukaanen J, Zhang H, Jamsa T, Vaananen $\mathrm{HK}$ : The mechanical strength of bone in different rat models of experimental osteoporosis. Bone 1994 ; 15 : 523-532

11) Ehara Y, Yamaguchi M: Histomorphological confirmation of bone loss in the femoralmetaphysical tissue of rats with skeletal unloading. Res Exp Med (Berl) 1996 ; 196 : 163-170

12) Osako $T$, Ohira $Y$, Ito G, Iwashita $Y$, Norikura $T$, Maki E: Structure and mineral content in weightbearing bones following hindlimb suspension in young rats. Jpn J Physiol 1991; 41 : 923-932

13）上田 敏 編: リハビリテーション基礎医学, 第 2 版. 医学畫院, 東京, $1994 ;$ pp 222-229

14）酒井昭典, 中村利孝：運動の骨代謝への影響. 総合リハ 1999; 27 : 111-115

15）黒河内和俊, 大森幸子, 村田善晴, 河野節子, 伊藤隆安, 神田和実, 妹尾久雄, 岩田 久: 別冊整形外科 骨粗鬆 症 $1998 ； 33: 16-19$

16) Umemura $Y$, Ishiko $T$, Yamauchi $T$, Kurono $M$, Mashiko S: Five jump per day increase bone mass and breaking force in rats. J Bone Miner Res 1997 ; 12 : $1480-1485$

17）梅村義久, 石河利寛，桜井佳世，益子詔次：ジャンプト レーニングがラットの骨形態・強度に及ぼす影響. 体 力医学 $1996 ; 45: 311-318$

18) Yeh JK, Aloia JF, Tiemey JM, Sprintz S : Effect of treadmill exercise on vertebral and tibial bone mineral content and bone mineral density in the aged adult rat: determined by dual energy X-ray absoptiometry. Calcif Tissue Int 1993; 52: 234-238

19) Yeh JK, Aloia JF, Chen MM, Tierney JM, Sprintz $\mathrm{S}$ : Influence of exercise on cancellous bone of the aged female rat. J Bone Miner Res 1993 ; 8 : 11171125

20) Bourrin S, Palle S, Pupier R, Vico L, Alexandre C: Effect of physical training on bone adaptation in 
three zones of the rat tibia. J Bone Miner Res 1995 ; 10: 1745-1752

21) Bourrin S, Genty C, Palle S, Gharib C, Alexandre C : Adverse effects of strenuous exercise: a densitometric and histomorphometric study in the rat. J Appl Physiol 1994 ; 76 : 1999-2005
22）山内秀樹, 米本恭三: 廃用性筋萎縮に対する等尺性運 動の効果と加齢の影響. リ八医学 $1997 ; 34: 46-51$

23) Maddalozzo GF, Snow CM: High intensity resistance training: effects on bone in older men and women. Calcif Tissue Int 2000 ; 66 : 399-404 